\title{
Human Rights and Palestine: The Right to Self-Determination in Legal and Historical Perspective
}

\author{
Curtis F. J. Doebbler \\ Geneva School of Diplomacy and International Relations, Webster University Geneva, Geneva, Switzerland. \\ Email: cdoebbler@gmail.com
}

Received June 28 ${ }^{\text {th }}, 2011$; revised July 26 $6^{\text {th }}, 2011$; accepted August $10^{\text {th }}, 2011$.

\begin{abstract}
The 'Question of Palestine', as it is known in the United Nations $(U N)$, is the longest unresolved human rights problem on the world organization's agenda. It is primarily a question about the right to self-determination of the Palestinian people. This is a right that, according to well-established international law, existed in favor of the indigenous inhabitants of Palestine and continues to exist today, although its exercise has been denied in violation of international law. This contribution examines the development of this right and how it exists today.
\end{abstract}

Keywords: Palestine, Human Rights, International Law, Self-Determination

\section{Introduction}

The 'Question of Palestine', as it is known in the United Nations (UN), is the longest unresolved human rights problem on the world organization's agenda [1]. It is the issue that perhaps more than any other tests the integrity and effectiveness of the international community's resolve to deal with human rights and to ensure respect for the rule of international law.

To understand the importance of Palestine in the context of the international community's commitment to international human rights law it is valuable to understand how this problem came on to the United Nations agenda in the first place. This is a question about which there is significant confusion, in part because it has usually been answered in political terms rather than by reference to the agreed norms of international law.

While the UN was created in 1945, the question of Palestine dates back to much earlier. For the better part of a century, Palestinians have been denied their most fundamental human rights and treated as second-class citizens of the international community. The most serious violation of human rights has involved the denial of the Palestinian people's right to self-determination. By claiming a religious, historical or ancient right to govern Palestine and its people the Zionist movement that became modern day Israel denied the majority of inhabitants living in Palestine their right to self-determination.

\section{The Legal Right of Self-Determination}

Self-determination is a right over which there has been some difference of opinion. Erin Jenne, for example, traces the idea back to around 1917 attributing its first expression to US President Woodrow Wilson [2]. Leenco Lata, a national liberation fighter turned academic, traces the concept behind the right to the $16^{\text {th }}$ Century Enlightenment [3]. Even these starting points, however, fail to take into account the historical efforts of the earliest organized human societies "to guard the independence of the social group [4]."

When in the $19^{\text {th }}$ Century in "Europe and Latin America the principle of nationalities appeared" it manifested itself as the principle of self-determination [5]. In accordance with the principle, whatever might have been the case concerning groups of people within already recognized states, ${ }^{1}$ groups of people not yet falling under the sovereignty of any state had the right to determine their own future. This principle was well established by 1928 when it was given significant support by the agreement of states not to use force as an instrument of foreign policy [6]. From this time onwards, the acquisition of territory by force, which had been previously allowed under international law, was now illegal. This point was em-

\footnotetext{
${ }^{1}$ The right of self-determination of people within existing states was carefully circumscribed by the principle of uti possidetis that made it very difficult to change existing national borders.
} 
phasized in article 2, paragraph 4 of the Charter of the United Nations, which prohibits the use force against the territorial integrity or political independence of a state. The Charter also reiterates the principle of self-determination.

Today the principle of self-determination is much better defined. It is recognized in leading human rights treaties [7-9], numerous UN resolutions [10,11], by the International Court of Justice (ICJ), ${ }^{2}$ and by the overwhelming majority of jurists as a leading principle of international law [12]. ${ }^{3}$ Some prominent jurists have even declared the right to self-determination to be a preemptory norm of international law or jus cogens [13]. And the ICJ has confirmed that the right to self-determination is of an erga omnes nature, thus supporting the interest of all states in ensuring its respect. ${ }^{4}$

As Professor Hannum has stated "perhaps no contemporary norm of international law has been so vigorously promoted or so widely accepted as the right of all peoples to self-determination [14].” Today, as South African Professor of Law John Dugard has observed, "the right of self-determination is a legal right under international law that is no longer seriously challenged [12]."

\section{Distinguishing Different Situations of Self-Determination}

To understand the right to self-determination it is relevant to understand the different situations to which it may apply and how it has been applied in these different situations. For each of these situations distinct rules and understandings of international law have developed.

The first situation is that of peoples living under colonialism or occupation [11]. ${ }^{5}$ While these people are part of an existing sovereign state they have a claim to their own independent sovereignty based on their right to selfdetermination. This right is created by the fact of colonialization - they have been conquered and subjected to the jurisdiction of a foreign state without their consent-or occupation by a foreign and oppressive occupier. This is the form of self-determination that is most widely accepted and which most clearly provides the right to one's own independent state. ${ }^{6}$ It applies to Palestine today according to numerous UN General Assembly resolutions [11]. Whether it applied in 1920 when Palestine became a Mandated territory is more controversial because this right is mainly the creation of the Charter of the United Nations and UN resolutions after 1945. There is good

${ }^{2}$ See, for example, Legal Consequences for States of the Continued Presence of South Africa in Namibia (South West Africa) notwithstanding Security Council Resolution 276, Advisory Opinion, ICJ Reports pp. 31-32, paras. 52-53 (1971) and Western Sahara, Advisory Opinion, ICJ Reports pp. 31-33, paras. 54-59 (1975).

${ }^{3}$ Citing several jurists who hold of this view at note 127 .

${ }^{4}$ Case Concerning East Timor (Portugal v. Australia), ICJ Reports 90 (30 June 1995).

${ }^{5}$ Also see Western Sahara Case, supra, note 2.

${ }^{6}$ Western Sahara, supra note 2, at pp. 12, 33, and 68. reason to believe that it did, however, as article 22 explicitly speaks about Mandated territories having the right to become "independent nations" [15].

The second situation to which self-determination applies is that of peoples who are part of an existing sovereign state. ${ }^{7}$ It is perhaps the most controversial form of self-determination. It is the form to which the principle of uti possidetis ${ }^{8}$ has the most relevance and consequently the form under which it is the most difficult to claim a right to an independent state, lacking evidence of significant oppression or massive violations of human rights. It is the right that Palestinians as part of the Ottoman Empire and which Jewish citizens of a Palestinian state would have. What is controversial about this right is not its existence today, but what it actually provides the peoples who are relying on it as a legal right. Likely it is limited to the right to have one's fundamental human rights respected and only to have the right to form an independent state when the existing sovereign has proved itself unable or unwilling to protect the fundamental human rights of the peoples claiming self-determination.

The third situation is that of peoples who are not part of any existing sovereign state. These peoples inhabit the land because they are indigenous since time immemorial, have inhabited it while under the authority of another state that has ceased to exist or has relinquished its title, or because they have through some other means acquired lawful title. In regards to this situation of self-determination it is important note that before 1928 title to territory could likely be acquired by the use of force or through conquest. In 1928 this change was agreed upon in the Kellogg-Briand Pact-as a principle of international law - and henceforth the acquisition of territory by force was no longer lawful. It is this third situation that applies most clearly to Palestine. While Palestine was part of the Ottoman Empire until World War I, afterwards it was only under British occupation. The fact that Britain never annexed Palestine nor exercised permanent sovereignty over it -instead agreeing to govern Palestine as a temporary Mandatory-consequently means that the right of self-determination always remained with the indigenous people without interruption since at least the end of World War I. Who inhabited Palestine hundreds or thousands of years ago is irrelevant. What is relevant is the nature of the government just before and just after 1928 and who were the indigenous people at this time. It is also relevant to understand whether these people ever voluntarily gave up their right to self-determination.

\footnotetext{
${ }^{7}$ See, for example, Aaland Island Case, LONJ (1920) Spec. Suppl., no. $3, p .3$ (holding that national minorities were not entitled to self-determination allowing the creation of an independent state).

${ }^{8}$ This principle protects the sanctity of international borders existing at the time of independence of a state.
} 


\section{The History of the Palestinian Self-Determination}

The history of Palestine goes back thousands of years. The Zionist movement [16] and even the Israeli government today make claim to the land based on historical or ancient title, which it is sometimes claimed has been ratified by more recent events [17].

The founders of Israel repeatedly point out that people have lived in the region that is generally known as Palestine for thousands of years. Indeed about two thousand years ago the region was inhabited by Jewish tribes, but even before that the earliest evidence of human presence in the region is of the Canaanites who were likely the decedents of people who migrated from the Arabian Peninsula around 3500 B.C. [18].

From $1200 \mathrm{BC}$ to about $133 \mathrm{AD}$ the Hebrew people were a considerable part of the population of the region known to the Romans as Judea and Assyria. At this time it was commonplace for one people to defeat another and take their land. Under the existing customs between people such transfers of land were part of usual affairs and usually were accompanied by the enslavement of the conquered people. In any event, the conquest of another people and their land was not illegal as the concept of modern international law did not even exist at the time.

The Arab population again moved into the region around $600 \mathrm{AD}$ bringing with them the Arab language and Islam. From the late 600's the region was ruled by a series of Arab-Islamic rulers cumulating with the Ottoman Empire's rule of the region. Using the 'Millet system' of local administration the Ottoman's ruled through the proxy of local rulers. Palestine, for example, was ruled from about 1840 to 1875 by the Arab tribal leader al-Zaidani. The Ottoman rule was only briefly interrupted by Napoleon's incursion into the region between 1799 and 1812 and by the armies of the Albanian ruler of Egypt Mohammed Ali between 1831 and 1840.

In 1880 about 20,000 Jews were living among a population of 450,000 Palestinians. The majority of the population of the region was Arab and this has remained true until today when all of the areas that were historically Palestine-both the occupied territories and the area the UN mandated to be Israel-is taken into account.

In the late 1800s, the Zionist movement was already acting to establish a Jewish homeland in Palestine, but it had not yet clearly manifested an intention to act in violation of the rights of the Palestinian people. After World War I the British occupied Palestine. The British conquerors under General Edmund Henry Allenby could have annexed the territory under existing rule of international law, but they did not.

Even when the British made the Balfour Declaration in
1917 there was no mention of a Jewish State, but rather only vague reference to a "national home for the Jewish people [19]." Understood in the context of international law, such a statement must have meant that a "national home for the Jewish people" would only be established in Palestine with the Palestinians' consent. Moreover, after a short period of military occupation and administration, the British agreed to administer Palestine as a mandatory power of the 'Allied Powers-created' League of Nations. The British were granted the League of Nations Mandate under article 22 of the Covenant of the League of Nations at a meeting held in San Remo, Italy on 24 August 1920 [20]. This Mandate set the terms, with Britain's agreement, by which the international community would ensure the fundamental right to selfdetermination of the Palestinian people. The Mandate was authorized by Article 22 of the Covenant of the League of Nations that governed its interpretation and implementation in relation to Palestine. The relevant part of this article states that

certain communities formerly belonging to the Turkish Empire have reached a stage of development where their existence as independent nations can be provisionally recognized subject to the rendering of administrative advice and assistance by a Mandatory until such time as they are able to stand alone. The wishes of these communities must be a principal consideration in the selection of the Mandatory [15].

The International Court of Justice (ICJ) described the League of Nations mandates as "created, in the interests of the inhabitants of the Territory, and of humanity in general, as an international institution with an international object-a sacred trust of civilization" and the "international rules regulating the Mandate" as "constituting an international status for the territory recognized by all the Members of the League of Nations...."9 A Mandate did not, in the words of the Court "involve any cession of territory or transfer of sovereignty" and the Mandatory exercised its responsibility "with the object of promoting the well-being and development of the inhabitants."10

Some writers have mischaracterized the League of Nations Mandate for Palestine as one that does not call for independence [21]. Article 22, however, indicates the Mandate described in the paragraph quoted above was the only Mandate applicable to communities "formerly belonging to the Turkish [Ottoman] Empire” [15]. The other Mandates were intended for societies which were not yet developed to the extent that they could govern

\footnotetext{
${ }^{9}$ The Legal Consequences for States of the Continued Presence of South Africa in Namibia (South West Africa) notwithstanding Security Council Resolution 276, Advisory Opinion, ICJ Reports 128, 132 (11 July 1950).

${ }^{10}$ Id. at $132-133$.
} 
themselves. Palestine had, however, achieved a significant degree of development by the later years of Ottoman rule and a large degree of self-sufficiency of government under the de-centralized system of Millet administration used throughout the Ottoman Empire [22]. The subsequent paragraphs of Article 22 must thus be read to apply to the more limited mandates concerning African and South Pacific communities. Indeed, the other Mandates make reference to these geographic regions and do not mention peoples who were living under the jurisdiction of the former Ottoman Empire.

In the Mandate for Palestine, the League of Nations makes it clear that it is being granted to Britain "for the purpose of giving effect to the provisions of article 22 of the Covenant to the League of Nations." ${ }^{11}$ This statement appears even before the Mandate text makes a brief preambular reference to the Balfour Declaration. The most important operative provision of the Mandate is perhaps article 2 stating that

the Mandatory shall be responsible for placing the country under such political, administrative and economic conditions as will secure the establishment of the Jewish national home, as laid down in the preamble, and the development of self-governing institutions, and also for safeguarding the civil and religious rights of all inhabitants of Palestine, irrespective of race and religion [15].

Other relevant articles of Mandate indicate that local autonomy is to be encouraged (art. 3), the Jewish agency is to be recognized as a public body that is distinct from but cooperates with Britain to implement the mandate (art. 4), the integrity of Palestinian territory must be respected (art. 5), and Jewish migration and the acquisition of "Palestinian citizenship by Jews" is to be 'facilitated' (art. 6 and 7) [15].

It has been argued that these provisions provide for the creation of a Jewish state and relegated indigenous Palestinians to mere secondary citizens in Palestine [23]. But according to established international law at the time, and today, this is unlikely to have been the case.

The Mandatory had the duty to assist in the creation of a state based on the wishes of the people living in Palestine. This is evident from the references to "independent nations," the right to "stand alone," and the "wishes" of the affected people or communities as "a principal consideration" in article 22 of Covenant [15]. As the foundational authority for the Mandate, article 22 of the Covenant controls its interpretation. Such an interpretation using the ordinary words of article 22 of the Covenant and the Mandate would appear to exclude the exercise of the Mandate in such a way as would deny the indigenous and majority of Palestinian people the right to create their

\footnotetext{
${ }^{11}$ Supra note 27, at p. 74, first preambular paragraph.
}

own nation or their right to self-determination.

The right to self-determination for peoples who were not subject to claims of permanent sovereign by a state provided for, and still provides today, for the recognition of the will of the local community to determine their own future. Thus by virtue of their right to self-determination the Palestinian people-about $80 \%$ of whom were Muslim or Arabs or both - had the right to decide their own future without the interference of any foreign state, including the Mandatory. Indeed Britain's legal obligation under international law was to facilitate the realization of the right to self-determination by the Palestinian people.

The British did not act on this responsibility. Instead, Britain worked with Jewish agencies and the Zionist Movement to allow the fate of the Palestinian's people to be decided by outsiders who occupied Palestine with the assistance of Britain [24]. Not only did this constitute the denial of the Palestinians right to self-determination, but it also violated Britain's legal obligations as Mandatory. In view of international law it created state responsibility for an internationally wrongful act. The result of such an act according to international law, is the creation of an illegal situation. And the consequences of an illegal situation include the duty for all states not to recognize the illegal situation created and the duty of the state creating that situation to stop doing so and to restore the original situation. These consequences are part of established international law.

The advent of World War II focused the attention of Palestinians of all persuasions on assistance to the allied powers. The Palestinians likely thought their British allies might favour their aspirations for independence, but nothing could have been further from the truth.

When the UN was formed by the Allied Powers, they did so with the guilt of the Nazi extermination of hundreds of thousands of Jews haunting them. There was likely an equal sense of guilt about the law and policies that had obstructed Jews from fleeing the persecution in Germany to the United States. When the UN began to consider the 'Question of Palestine' immediately after its creation it is not surprising therefore that both guilt and past practices coloured its views. There was the feeling of a need to provide the Jews an alternative to Germany, while at the same time the lingering unwillingness of the Allied Powers to accept Jewish migrants. Sending them to Palestine must have seemed a convenient way out. This was not immediately apparent to Palestinians and their Arab neighbours. The Arab delegation to the September 1946 meetings in London discussing the future of Palestine naively proffered constitutional proposals calling for an independent Palestine made up of all Palestinians [25]. These calls for an independent Palestinian state were ignored. 
While Arab efforts were characterized by their commitment to the self-determination of the Palestinian people through the creation of a Palestinian state, the Zionist efforts were aimed at creating a Jewish state, in Palestine, preferably without indigenous Palestinians. They set about this through the intensified purchase of Palestinian land, migration of Jews from abroad, lobbying of western powers especially the United States, and the conduct of violent attacks against Palestinian and British targets. As a result the violence in Palestine increased significantly; first because of attacks carried out by the Zionist movement and then because of Palestinians attacks in response as they increasingly recognized that their right to self-determination was being denied. Eventually, the British withdrew from Palestine.

Before withdrawing the British had brought the 'Question of Palestine' before the UN in February 1947. The Palestinians were represented by the Arab Higher Committee, while the Zionists were represented by the Jewish Agency for Palestine. More importantly however, were the states behind these two representatives. The Palestinians were supported by Arab states that were just establishing themselves and in some cases emerging from colonization. The Zionists were supported by the wealthy Allied Powers, especially the United States, which had even profited from the war, and the British, the then-Mandatory over Palestine. The Arab states immediately called for an end to the British Mandate and the creation of an independent Palestinian state. This was however blocked by the Allied Powers who had committed themselves to creating a Jewish state in Palestine. Instead a UN Special Committee on Palestine was formed. This Committee several times called for the urgent creation of a Palestinian state in which all Palestinians could live together [26]. It also reported on the Partition Plan, informing the UN General Assembly that it was "contrary to the specific provisions of the Mandate and in direct violation with the principles and objectives of the Covenant," moreover that the "imposition of partition on Palestine against the express wishes of the majority of its population can in no way be considered as respect for or compliance with" the Charter of the UN, including the Palestinians' right to self-determination [27]. The General Assembly was thus unambiguously informed that the Partition Plan would violate international law-including the right to self- determination that is enshrined in article 1 of the Charter of the UN.

The UN Special Committee on Palestine nevertheless submitted two plans. One called for partition and the other for a federal Palestinian state. On 23 September 1947 the UN General Assembly formed an Ad Hoc Committee to consider the two plans that were before it. In turn, the Ad Hoc Committee created two Sub-Committees, which were again split between non-Arab and largely Arab and Arab-sympathizing states [28]. These Committees rendered recommendations [28]. As one might have imagined Sub-Committee 1 consisting of non-Arab states, they recommended adoption of the Majority Plan with only slight modifications [29]. Sub-Committee 2-which had divided itself into three Working Groups to consider respectively the Legal Problems, the Refugee Problem and Constitutional Proposals and which reported first-made several recommendations, including the recommendation that an Advisory Opinion be requested from the International Court of Justice [30]. The recommendations were put to a vote and the recommendation to seek an Advisory Opinion on the legality of the partition plan from International Court of Justice failed to get sufficient votes [31]. It is noteworthy that the representative of the Arab Higher Committee addressing the UN General Assembly Ad Hoc Committee opposed the Sub-Committee 1 plan based on the fact that it constituted a "monstrous perversion of the principle of self-determination in Palestine" [32]. Consequently, four draft resolutions were presented to the Ad Hoc Committee. All three presented by Sub-Committee 2 (calling for the Advisory Opinion, calling for action to assist Jewish refugees, and calling for the establishment of a single state of Palestine) were rejected [32]..$^{12}$ The single resolution for Sub-Committee 1 calling for adoption of the partition plan was adopted [32]. ${ }^{13}$ The Ad Hoc Committee sent this recommendation to the General Assembly, which began to consider it on 26 September 1947.

Within three days UN General Assembly Resolution 181 (II) was adopted on 29 November 1947 based on the recommendation. This UN General Assembly resolution called for the creation of two states, one Arab and one Jewish, while Jerusalem was to remain under a special international regime [33]. It created Israel on $56 \%$ of Palestine, despite it having less than $35 \%$ of the population many who had been recently imported. Palestine was left with just $44 \%$ of its own territory. After the adoption of resolution 181, several other re- solutions were adopted by the General Assembly that attempted to mitigate the worst effects of the human rights violations caused to the Palestinian people [34].

The UN Security Council became involved when it appeared that the British Mandatory could no longer maintain peace and security in Palestine in the face of mainly Israeli bombings of civilians and civilian administrative targets. The Security Council met several times between 24 February and 14 May 1948 [35]. It adopted five relevant resolutions mainly appealing for peaceful resolution of the dispute between Arabs and Israelis or

\footnotetext{
${ }^{12}$ At 1633-34.

${ }^{13}$ At 1637.
} 
calling for action that was already too late, but never ordering timely concrete action be taken on the ground as its mandate allowed it to do [36-40].

During this time the Trusteeship Council, which was responsible for guiding the decolonization of newly independent countries, was confined to the role of dealing with the internationalization of Jerusalem. To this end it adopted several resolutions [41-44] that established the foundation for the international consensus that Jerusalem did not fall under the sovereignty of Israel.

On 15 May 1948 the United Nations ended the Mandate of the British over Palestine, but even before it had done this the independence of the State of Israel was declared on 14 May 1948. The Palestinians and the Arab states objected. The Arab states came to the aid of the Palestinians, but with only a token force of about 20,000 soldiers the next day [45].

The Security Council reacted by focusing on the issue of maintaining peace, without concern for the right to self- determination or any other basic human rights of the Palestinian people. It adopted a resolution calling for an Armistice that treated both parties as being of equal fault in the instigation of hostilities [46]. Despite the Security Council's apparent bias, the Arab countries one by one responded by entering into General Armistice Agreements with Israel between February and July 1949 [47]. These Armistice Agreements often gave the UN the role of patrolling a Demilitarized Zone, which by the UN's own admission became zones from which Palestinians were deported and not allowed to return [47]. ${ }^{14}$

Several other armed confrontations ensued in the next twenty-two years. As a consequence, what Israel was 'offering' the Palestinians dwindled from the Mandate territory to just about $7.5 \%$ of this territory by the start of the $21^{\text {st }}$ century. ${ }^{15}$ In other words, today Palestinians are being offered less than $10 \%$ of the land to which they are entitled under international law. This already restricted entitlement has continued to dwindle away through Israel's subsequent practices such as the building of a separation Wall, the ad hoc confiscations of land for settlements, and the latest decision to begin deporting Palestinians from Palestinian land.

\section{Evaluating Palestinian Self-Determination and the Creation of Israel}

The Zionist movement and later the Israeli authorities immediately claimed that the UN General Assembly Resolution 181 created the Jewish state of Israel. In reality, however, as indicated above, Israel's independence was claimed even before it was intended to be granted by the

\footnotetext{
${ }^{14}$ At 57 and 58 citing the comments of UN Chief of Staff General Riley.

${ }^{15}$ This figure is based on the original League of Nations' Mandate as compared with what Israeli Prime Minister Ariel Sharon was offering in this 2000 'Peace Plan'.
}

UN. As a consequence Israel's declaration was both a violation of the still existing League of Nations Mandate and a violation of the Palestinian peoples' right to self-determination, both of which contain international legal obligations.

Furthermore, Israel's claim to be created by the UN General Assembly appears to be based on the fact that the UN General Assembly Resolution had legally binding authority. Nothing in the Charter of the UN provides for such authority. In fact the Charter expressly states that the UN General Assembly makes "recommendations" (art. 10 - 14), except, for example, on the limited subjects of budgetary matters (art. 17) and the admission of new States[48].

The Zionist movement also relied on UN General Assembly Resolution 181 to claim their own right to self-determination. While they undoubtedly had this right, it was the right to self-determination with- in a state and not to their own state in violation of the right to self-determination of the Palestinian people. Their claims were valid vis-à-vis a Palestinian state. They include the human right to be treated equally with all Palestinians with respect for their fundamental human rights. History had shown that this was indeed possible.

The main challenge to the legitimacy of the creation of Israel is the fact that it violated a fundamental right of the Palestinian people. Israel's creation violated the human right of the Palestinians - the overwhelming majority of the indigenous population of Palestine- to self-determination. Moreover, the UN General Assembly was aware of this violation because of the reports of its own Committees. Whether the UN General Assembly could ignore this warning and act contrary to the Charter of the UN is doubtful. As already indicated, the UN General Assembly is a principal organ of the UN. It is bound by the purposes of the UN that are stated in article 1 and by the duty to respect the right to self-determination that is stated in article 55 of the Charter of the UN. Nevertheless, the General Assembly did ignore the advice of the UN Special Committee on Palestine and adopted Resolution 181 containing a recommendation for a Partition Plan dividing Palestine into two states [33].

The fact that the UN General Assembly acted by making a recommendation has a consequence for the legality of its actions. Although a recommendation that is consistent with international law might be considered to 'reflect' international law, a recommendation that is contrary to international law must be interpreted consistent with existing international law. If one accepts that the right to self-determination-at least for people not subject to the permanent sovereignty of any other stateexisted when the UN was created in 1945 then the UN General Assembly recommendation in Resolution 181 
must be interpreted in a manner that is consistent with the Palestinians' right to self-determination. Such an interpretation is also supported by the fact that when Resolution 181 was adopted the League of Nations Mandate over Palestine was still in effect. The League of Nations Mandate recognized that the Mandatory administered Palestine in sacred trust for its inhabitants and that these inhabitants must determine the future of their homeland in accordance with their will. The will of the Palestinian people was never allowed to be exercised because General Assembly Resolution 181 was interpreted to deny the Palestinians' voice in their own future-a fragrant violation of their right to self-determination.

Finally, the claim that the League of Nations Mandate, by incorporating reference to the Balfour Declaration and its language, created the right to Jewish state of Israeli state is also in- consistent with the right of every people not under the permanent sovereignty of a state to self-determination that already existed at the time. The Mandate must thus be interpreted consistent with the right of the indigenous people to determine their own future, including their express right to create an independent state. To do so otherwise would run counter to the principles stated in the Covenant of League of Nations and in the Mandate itself and existing customary international law.

Today the denial of the Palestinian peoples' right to self-determination still remains the single greatest obstacle to ensuring human rights in Palestine and perhaps the greatest test of the international community's commitment to the rule of international law and human rights everywhere in the world.

\section{Acknowledgements}

The author is grateful to Ms Gala Maric, my assistant, for her proofreading of this paper as well as Mr. Tomas Solfaro for his formatting and checking of footnotes. He is also grateful to the editorial staff who remained patient throughout the long process that it took to approve this publication for their commitment and integrity. And finally the author wishes to thank Prof. Isabel Trujillo of the Department of the Study of Politics, Law and Society at Università di Palermo for providing useful comments on earlier versions of this paper.

\section{REFERENCES}

[1] United Nations, "The Question of Palestine and the United Nations,” New York, 2008, p. iii.

[2] E. Jenne, "National Self-Determination: A Deadly Mobilizing Device," In: H. Hurst and E. F. Babbitt, Eds., Negotiating Self-Determination, Lexington Books, Lanham, 2006, pp. 7-8.
[3] L. Lata, "The Horn of Africa as Common Homeland: The State and Self-Determination in the Era of Heightened Globalization,” Wilfrid Laurier University Press, Waterloo, 2004, p. 15.

[4] W. Rodney, "How Europe Underdeveloped Africa," Howard University Press, Washington, D.C., 1982, p. 4.

[5] I. Brownlie, "Principles of Public International Law," 6th Edition, Oxford University Press, Oxford, 2003, p. 124.

[6] "General Treaty for Renunciation of War as an Instrument of National Policy,” League of Nations Treaty Series, Vol. 94, 1928, p. 57.

[7] "International Covenant of Civil and Political Rights," United Nations Treaty Series, Article 1, Vol. 999, 1966, p. 171.

[8] "International Covenant of Economic, Social, and Cultural Rights,” United Nations Treaty Series, Vol. 993, Article 1, 1966, p. 3.

[9] “African Charter on the Human and Peoples' Rights," Organization of African Unity Document Number CAB/LEG/67/3/rev.5, Article 20, 1982.

[10] "Declaration on Principles of International Law concerning Friendly Relations and Co-operation Among States in Accordance with the Charter of the United Nations," United Nations General Assembly Resolution. 2625 (XXV), 1970.

[11] "Declaration on the Granting of Independence to Colonial Countries and Peoples,” United Nations General Assembly Resolution 1514 (XV), 1960.

[12] J. Dugard, "International Law: A South African Perspective,” JUTA and Co., Ltd., Capetown, 3rd Edition, 2006, p. 103.

[13] H. G. Espiell, "Self-Determination and Jus Cogens," In: A. Cassese, Ed., UN Law/Fundamental Rights: Two Topics in International Law, Martinus Nijhoff Publishers, Alphen an den Rijn, 1979, pp. 167-173.

[14] H. Hannum, “Autonomy, Sovereignty, and Self-Determination: The Accommodation of Conflicting Rights," 2nd Edition, Cambridge University Press, Cambridge, 1996, p. 27.

[15] "Treaty of Peace Between the Allied and Associated Powers and Germany, The Protocol Annexed Thereto, The Agreement Respecting the Military Occupation of the Territories of the Rhine, and the Treaty Between France and Great Britain Respecting Assistance to France in the Event of Unprovoked Aggression by Germany,” Covenant of the League of Nations, Adopted at Versailles, 28 June 1919, p. 188.

[16] D. Ben Gurion, “The Rebirth and Destiny of Israel,” Philosophical Library, New York, 1954, p. 100.

[17] H. Grief, “The Legal Foundation and Borders of Israel Under International Law,” Mazo Publishers, Jerusalem, 2008, p. 18.

[18] J. Quigley, "Palestine and Israel: A Challenge to Jus- 
tice,” Duke University Press, Durham, North Carolina, 1990, pp. 66-72.

[19] “Balfour Declaration,” 2 November 1947. In: Mahdi Abdul Hadi, Ed., Documents on Palestine, Passia Publications, Jerusalem, 2007, p. 33.

[20] “The British Mandate for Palestine,” 24 August 1920. In: Mahdi Abdul Hadi, Ed., Documents on Palestine, Passia Publications, Jerusalem, 2007, pp. 74-78

[21] R. H. Eiseman, “Islamic Law in Palestine and Israel,” E.J. Brill, Leiden, 1978, p. 74.

[22] A. Carmel, "A Note on The Christian Contribution to Palestine's Development in the $19^{\text {th }}$ Century,” In: D. Kushner, Ed., Palestine in the Late Ottoman Period: Political, Social, and Economic Transformation, E.J. Brill, Leiden, 1986, pp. 301-302.

[23] J. Strawson, "Mandate Ways: Self-determination in Palestine the "Existing Non-Jewish Communities," In: S. R. Silverburg and R. Stanford, Ed., Palestine and International Law, McFarland, Jefferson, North Carolina and London, 2002, pp. 251-270.

[24] League of Nations, "Interim Report of the Civil Administration of Palestine during the Period 1 July 1920- 30 June 1921,” The Report of the British Government as the Mandate Holder, 30 July 1921.

[25] "Constitutional Proposals of the Arab States' Delegations to the Palestine Conference," 30 September 1946. In: Mahdi Abdul Hadi, Ed., Documents on Palestine, Passia Publications, Jerusalem, 2007, pp. 458-459.

[26] "Summary of the Report of the UN Special Committee on Palestine (UNSCOP) Regarding the Partition Plan,” Passia Publications, Jerusalem, 31 August 1947, pp. 467-469.

[27] "Report of the UN Special Committee on Palestine (UNSCOP) Regarding the Partition Plan (Excerpts)," 29 November 1947, In: Mahdi Abdul Hadi, Ed., Documents on Palestine, Vol. I, Passia Publications, Jerusalem, Paragraph 19, p. 514.

[28] S. Hadawi, United Nations Resolutions on Palestine 1947-1966 xiv-xix (Revised Edition, The Institute for Palestine Studies, Beirut, 1967) for a brief, but insightful discussion of the work of these two Sub-Committees as well as the Ad Hoc Committee of the UN General Assembly.

[29] United Nations Document Number A/AC 14/34, 19 November 1947.

[30] United Nations Document Number A/AC 14/32, 11 November 1947.
[31] United Nations General Assembly Official Record, 2nd Session, Ad Hoc Committee on the Palestine Question at p. 203.

[32] United Nations General Assembly Official Record, 2nd Session., Summary record of meetings of the Ad Hoc Committee from 25 September to 25 November, Vol. II, 19 November 1947, pp. 150, 199-201.

[33] United Nations Generel Assembly Resolution 181 (II), UN Document A/Res/2/181, 29 November 1947.

[34] United Nations Generel Assembly Resolution 194 (III), Calling for the Right of Return and for Compensation for Palestinian Refugees, 11 December 1948.

[35] H. Cattan, "Palestine and International Law," 2nd Edition, Longman, London, 1973, p. 21.

[36] United Nations Security Council Resolution 42, Calling for the Restoration of Law and Order, 5 March 1948.

[37] United Nations Security Council Resolution 43, Calling for a Truce between Arabs and Israelis, 1 April 1948.

[38] United Nations Security Council Resolution 44, Calling for a United Nations General Assembly Special Session on Palestine, 1 April 1948.

[39] United Nations Security Council Resolution 46, Calling for the Cessation of All Military Activities, 17 April 1948.

[40] United Nations Security Council Resolution 48, Calling for the Establishment of a Truce Commission, 23 April 1948.

[41] United Nations Trusteeship Council Resolution No. 29(II), 11 December 1947.

[42] United Nations Trusteeship Council Resolution No. 32(II), 10 March 1948.

[43] United Nations Trusteeship Council Resolution No. 33(II), 10 March 1948.

[44] United Nations Trusteeship Council Resolution No. 34(II), 21 April 1948.

[45] E. O’Balance, “The Arab-Israeli War, 1948,” Providing a well-documented account of the 1948 war, New York, Praeger, 1956

[46] United Nations Security Council Resolution 62, Calling for an Armistice to be Established, 16 November 1948.

[47] F. Yahia, "The Palestine Question and International Law," The Institute for Palestine Studies, Beirut, 1970, p. 53.

[48] “Charter of the United Nations,” Articles 1 and 55, 1945. 